\title{
LA PERFORMANCE DE LOS JUEGOS FLORALES DE 1914 Y LA INADECUADA PRESENCIA DE GABRIELA MISTRAL EN ELLOS ${ }^{1}$
}

\author{
María de la Luz Hurtado \\ Pontificia Universidad Católica de Chile \\ dhurtadm@uc.cl
}

\section{LOS JUEGOS FLORALES DE 1914: UN CEREMONIAL INSCRITO EN LA BELLE EPOQUE}

Cuando se plantea la interrogante de por qué Gabriela Mistral no concurrió a recibir el premio de La Flor Natural en los Juegos Florales de Santiago de 1914 obtenido con sus Sonetos de la muerte, perdiendo la oportunidad de acelerar su inserción en los circuitos artístico-intelectuales del momento, se piensa que ella estuvo ausente de una ceremonia en la que primaba la sonoridad de la palabra, como ocurre en la actualidad en las premiaciones de concursos literarios. Sin embargo, el entramado de lenguajes y de componentes sociales que articulaban los Juegos Florales en Chile y en el mundo en ese inicio del siglo xx era de una alta complejidad, por lo que el análisis de su especificidad es necesario para desentrañar no solo el enigma de la inasistencia de la Mistral a ese evento sino una cuestión más significativa: el concepto de poesía y de poeta que encarnaban estos Juegos, en peculiar organicidad con los poderes dominantes y con las matrices civilizatorias de ese tiempo.

La exploración de este entramado arroja perspectivas que permiten cuestionar que estos Juegos Florales hayan implicado la aceptación de Gabriela Mistral como figura

${ }^{1}$ Este artículo es parte del proyecto Fondecyt No 1060528 "Género, etnia y clase en el teatro chileno de la primera modernidad: 1900-1918" del cual soy investigadora responsable. En él reformulo materiales de mi tesis doctoral en Literatura de la Universidad de Chile, 2004: "Performances de la sociedad civil en tensión con la modernidad. Chile 1870-1918". 
pública en la alta sociedad chilena (Catalán 130) y, por el contrario, demostrar que fueron excluyentes de ella. Así mismo, permite calibrar la transgresión que esta poetisa realiza de la lógica de dichos Juegos, e interpretarla como parte del descentramiento social y cultural de los poderes hegemónicos que ya algunas mujeres en Chile y en el mundo estaban realizando desde renovadas prácticas culturales agenciadoras de lo subalterno en el seno de lo neo-colonial.

Ubico a estos Juegos Florales en el ámbito de lo neo-colonial, porque los realizados en Chile actualizaban, desde lo peculiar de nuestra configuración socio-histórica, un modelo de certamen poético/performativo vigente en los principales centros urbanos en los que regía la hegemonía europea y la sensibilidad de la Belle Epoque, siendo una manifestación del poderoso referente mundial constituido por Europa a la fecha, dada su formidable expansión territorial, económica y cultural, al punto de que Hobsbawm designa a este periodo como la "Época del Imperio"2.

La opulenta dinámica festiva de la alta burguesía europea vinculada a las noblezas aún vigentes fue vivida como una Belle Epoque, desplegándose en el espacio público mediante manifestaciones de la modernidad secular impregnadas por formas de "publicidad representativa" evocativas de las empleadas en las cortes del Antiguo Régimen (Habermas) ${ }^{3}$. Esto se dio en medio de abismales contrastes sociales, por lo que fue un baile sobre las cabezas y cadáveres de los desposeídos. Chile experimentó este periodo de modo parecido, ya que su oligarquía se sumó a la ritualidad de gasto y exhibición de esa época imperial, apoyada en que poseía la mayor concentración de la propiedad a nivel mundial en sectores clave de la economía, en tanto el país sufría tasas de mortalidad similares a los más pobres países africanos (Collier y Sater 148 y 161).

Los Juegos Florales estaban inscritos en el "nuevo régimen visual" de la modernidad iniciado en la segunda mitad del siglo XIX (Dias 39), en el cual el ojo fue el órgano privilegiado del conocimiento. En la producción y circulación del saber cultural se creaban lenguajes visuales que establecían "lo digno de ser visto" al tiempo que prefiguraban "los modos de ver", soliendo poner cuerpos y objetos en exhibición ante la mirada pública a modo de espectáculo de acuerdo con códigos diferenciadores de tipo jerárquico en relación con razas, géneros, culturas, civilizaciones ${ }^{4}$.

2 "Europa (en la Época del Imperio, 1875-1914) era no sólo el núcleo original del desarrollo capitalista que estaba dominando y transformando el mundo, sino con mucho, el componente más importante de la economía mundial y de la sociedad burguesa. No ha habido nunca en la historia una centuria más europea ni volverá a haberla en el futuro" (2627).

${ }^{3}$ Estas ponían al cuerpo del monarca y de sus cortesanos en exhibición ante el pueblo, portando signos de poder económico y cultural en tanto sus vestuarios, accesorios, maquillajes, etc. ostentaban riqueza y originalidad, copando el espacio público con su presencia aparatosa y exclusiva, imposible de ser replicada por los otros estamentos sociales.

${ }^{4}$ Según el organicismo social y las teorías fisiognómicas, el escrutinio del cuerpo humano en relación comparativa entre sí e inserto en un medio natural/social, permitía su codificación 
Ya Baudelaire y luego Nietzsche captaron que la modernidad en la segunda mitad del siglo XIX, al romper con los rituales de coparticipación de las comunidades primarias, se espectaculariza a sí misma desde la "pura representación", de modo equivalente a como lo hacen otras formas de intercambio simbólico capitalista, deviniendo esta escisión en una limitación de la libertad humana. Tal como lo elabora Debord,

Toda la vida de esas sociedades en las que las condiciones modernas de producción prevalecen se presentan a sí mismas como una inmensa acumulación de espectáculos. Todo lo que antes era vivido directamente ha devenido pura representación. El espectáculo no es una colección de imágenes; más bien, es una relación social entre personas que es mediada por las imágenes. ...entendido en su totalidad, el espectáculo es tanto el resultado como la meta del modo de producción dominante. ...Lo que crea el poder abstracto de la sociedad también crea su abstracta falta de libertad (8).

Según Rojo, en esta Época del Imperio, la "parafernalia modernista" se valió de la "inscripción del dinero en los objetos" -el dinero, esa ecuación de representación fetiche en la era del capitalismo financiero- para poner en el centro del espectáculo social a algunos (los en situación de permitírselo), a la par que desplazando y humillando a otros (a los desposeídos) ${ }^{5}$. Ese exultante ejercicio del poder albergaba, no obstante, su propia contradicción y amenaza de finitud, ya que se vivía "la primera crisis del capitalismo" que derivaba hacia un "capitalismo organizado" (Wagner). Proliferaban grupos y clases sociales - medias, obreros, artesanos, mujeres-que, en tanto irrumpían al unísono en el espacio público monopolizado por las burguesías a través del siglo XIX, fueron accediendo a cuotas de poder y transformando las dinámicas sociales. Pero no siempre estos grupos que diversificaban el espectro de lo social y del género podían o querían hacerlo desde una lógica diversa, sino que solían propiciar espacios híbridos articulados desde lo hegemónico, los que no obstante, dejaban intersticios en los que otros modos de subversión afloraban por caminos inesperados.

Dentro del estudio que realizo en torno a las performances realizadas en los teatros de la Belle Epoque chilenos como locus de inscripción de proyectos y prácticas culturales de la modernidad neo-colonial, la situación producida por el hecho de que Gabriela Mistral fuera la ganadora de la Flor Natural en los Juegos Florales de Santiago de 1914

en tanto sus características visibles eran entendidas como signos, tal como las propiedades de la materia eran concebidas como manifestación de un sistema biológico sorprendido en un momento dado de su evolución.

5 "Es el dinero, a través de la profusión de signos que lo exhiben ante los ojos enardecidos de la muchedumbre, es decir, ante los ojos de todos aquellos que no lo poseen pero que lo desean y ambicionan a rabiar. Esos signos suministran la parafernalia modernista por antonomasia" (Rojo 186). 
organizados por una cierta élite intelectual y artística chilena en alianza con la élite social, devela estas dinámicas en flujo entre lo dominante y la emergencia de lo subalterno. Esto, al desafiar la poetisa la parafernalia modernista que sustentó dichos Juegos, primero desde el gesto de sustraer su cuerpo al espectáculo y a su lógica performativa para luego afirmar su presencia, en tanto clase/etnia y género, desde el poder transgresor de su palabra poética.

Mi hipótesis es que el tipo de performance realizada en este "magno concurso de arte, lujo y belleza" (Santiván, Confesiones) explica en parte que Gabriela Mistral, la primera mujer premiada en un certamen nacional de esta categoría, no subiera al escenario del Teatro Santiago a recitar sus sonetos y recibir su premio ese 22 de diciembre de 1914. Las justificaciones esgrimidas fueron que se debió a su "excesiva modestia de carácter", según explicó Víctor Domingo Silva en la ocasión, o, como le escribiera ella a Magallanes Moure al día siguiente, por preferir espacios de intimidad -“unos momentos solo en la multitud me hacen daño" (Cartas 23).

Sin embargo, más allá de lo dicho entonces, la dinámica performativa de estos juegos fue excluyente de su presencia/cuerpo, por representar la Mistral un género incongruente y anómalo respecto a lo esperado en un poeta laureado, sujeto idealizado de la relación poeta/musa, adecuación post-romántica a la medieval relación trovador/dama. Y más aún, un cuerpo con agravantes marcas de etnia y clase refractarias al ideal dominante de lo femenino en esa Belle Epoque ${ }^{6}$ : el de la mujer-flor.

\section{CAMPO CULTURAL: LA SAECH, ORGANIZADORA DE LOS JUEGOS FLORALES DE 1914}

La Belle Epoque suele adoptar los ropajes de las épocas consideradas cúspides de la historia occidental, no precisamente de las republicanas, sino de las de poderío político y/o de sociabilidad ostentosa de las noblezas y cortes europeas. La recuperación en esta época de los Juegos Florales originados en la Provenza francesa corresponde a ese interés por remitirse a la historia esplendente para cargar al presente con su halo. El ceremonial que los constituyó era afín a la sensibilidad de las élites modernas, las que lo adoptan, resignificándolo.

Simona, en la revista Familia, cuenta que, según la leyenda, estas gestas se iniciaron en Toulouse, hacia 1324; duraban varios días e incluían desfile de reinas, fallo del tribunal, distribución de recompensas, aclamación de los poetas galardonados en cabalgata triunfal por la ciudad. Habrían nacido en primavera, con el lema "bella estación, juventud del año, nos vuelves a traer los dulces juegos del amor". En la concepción cortesana, la poesía era el lugar de realización del "juego del amor", y la gestora de los Juegos fue justamente una mujer enamorada, Clemencia Isaura, quien los fundó

\footnotetext{
${ }^{6}$ Siguiendo a Butler, habría "cuerpos que importan", con-formados desde discursos normativos que van constituyendo al género y a la clase esperados y valorados, obligando a los sujetos a ubicarse sobre, más acá o más allá de esas líneas prefiguradas.
} 
en recuerdo de su amado, muerto en combate por su rey. Clemencia se reservó el privilegio de entregar las "alegrías" o premios florales a los ganadores, "los que son muy dignos de haber sido concebidos por una alma delicada de mujer y de poesía: la violeta, la eglantina, los suspiros de oro fino".

En los albores del siglo xx, los Juegos Florales se iniciaban invocando a esta mítica figura, inmortalizada en diversas esculturas y pinturas que la presentan según el tipo ideal de cada época ${ }^{7}$. Mujer que en los tiempos fundantes integraba la tribuna de los jueces, ante la cual los poetas leían sus obras, recibían de sus manos los premios florales y desfilaban en cabalgaduras, luciendo su apostura ante ella y la multitud ciudadana.

En Chile, los Juegos Florales se inauguraron en Valparaíso en 1910, con las fiestas del Centenario. Continuaron en esa y otras ciudades, realizándose en Santiago en 1914, cuando la Sociedad de Artistas y Escritores de Chile (SAECH), presidida por Manuel Magallanes Moure, convocó a este concurso nacional de "poesía, comedia y teatro". Fue mantenedor de los juegos Víctor Domingo Silva y su organizador, el secretario de la Sociedad, Fernando Santiván. Ellos especificaron el esquema performativo general de los Juegos Florales a través de múltiples decisiones respecto al para qué, dónde, con quiénes, cómo, etc. En este ejercicio, realizaron una cualidad propia de la modernidad: el que esta, siendo una sola en cuanto matriz civilizadora, es diversa en su configuración histórica, por lo que los Juegos Florales de Santiago no fueron una "imitación" de los Juegos europeos, sino que se experimentaron en consonancia con la realidad histórica nacional en que se actualizaron ${ }^{8}$. La apropiación realizada da luces acerca de la conformación del campo cultural (Bourdieu) en que se desenvolvieron y del modo en que quisieron insertarse en él y reconfigurarlo a través de su acción poéticocultural, desatando diversas dinámicas que hicieron aflorar fenómenos más amplios cuya tensión manifestaba nuevas tendencias hasta ahora no reconocidas ni integradas.

El campo cultural latinoamericano hacia 1910 fue perfilado por Rama como experimentando un proceso desde la ciudad modernizada a la polis politizada y la ciudad revolucionada (71-174). En una animación y diversificación creciente, transitaba desde vértices de lo privado hacia lo cívico-público, desde lo estamentario jerárquico al entrecruce social, desde lo provinciano a lo capitalino y cosmopolita, y desde lo académico a lo doctrinario libertario y autodidacta.

En Santiago, en el ámbito de la institucionalidad literaria, continuaba su cultivo en círculos semi cerrados de salón, pero cundían asociaciones insertas en el espacio público, como el Ateneo, fundado en 1889 y replicado a través de Chile, que estimulaba la difusión y reflexión crítica de esta actividad mediante recitales, conferencias y concursos.

${ }^{7}$ Como una sensual Safo griega, con los cabellos escapando coquetamente del blanco velo monástico del siglo XIV o vestida con las galas enjoyadas de una mujer de alcurnia del siglo $\mathrm{xV}$, coronada de flores.

8 "Ninguna modernidad, por ejemplo la francesa, es modelo para las otras, ya que la modernidad no es un fenómeno que se desarrolla por imitación; se trata de un conjunto de cambios internos en la historia específica de cada país" (Ortiz 9 y10). 
La especialización del oficio se expresó en la fundación de asociaciones gremiales, como la SAECH, que buscaba cultivar, ampliar y defender el oficio, elevar la calidad de su producción y obtener difusión y reconocimiento público ${ }^{9}$. La directiva de 1914 de la SAECH expresa la amplitud y límite de sus integrantes: miembros vinculados a la élite social, como Magallanes ${ }^{10}$, comparten la conducción de la institución con escritores de clase media inmigrantes de la provincia ${ }^{11}$, como Santiván y Silva, sin que ninguna mujer integre la directiva, aun cuando ya muchas publicaban a la fecha.

No obstante, en este campo literario existía aún una tensión entre miembros de la oligarquía y de las clases medias, como lo evidencia el tipo de vínculo existente entre Iris y Santiván ${ }^{12}$. En todo caso, a diferencia de escritores identificados con lo popular, como Recabarren o Acevedo, que privilegiaban circuitos enclavados en la base social, instituciones pluriclasistas como el Ateneo operaban dentro de los circuitos dominantes, aceptando el padrinazgo y la prestigiosa aura de las elites sociales en sus actos públicos ${ }^{13}$. Esta actitud podría explicarse porque, según los historiadores, las clases

${ }^{9}$ Un año después, en 1915, se funda la Sociedad de Autores Teatrales de Chile en la que participan muchos miembros de la $\mathrm{SAECH}$, especializando aún más sus vínculos en torno a un género literario: el dramático (nominado "comedia" en los Juegos Florales de 1914).

${ }^{10}$ También nacido en una ciudad de provincia, La Serena, siendo su padre un afamado abogado.

${ }^{11}$ Es sabido que las clases medias en esta época estaban en constitución en Chile, y que los nichos de movilidad social de sus intelectuales eran los empleos dentro del Estado, junto al ejercicio de las letras en la prensa, la literatura, la academia.

${ }^{12}$ La relación entre la escritora Iris (Inés Echeverría) y Fernando Santiván evidencia cómo la cuestión de la clase se interponía en las relaciones entre intelectuales. Santiván, al asistir en 1909 al salón de Iris, confiesa la siguiente aprehensión: “¡La vida santiaguina! Aquella aristocracia desdeñosa altiva, impenetrable para los que no pertenecen a su círculo ... quedábame en suspenso ante aquellas gentes... que poseían un lenguaje propio, aun dentro de la ignorancia, y cuyos ceremoniales gestos y tono de voz creaban una especie de idioma francmasónico intraducible para el profano" (Confesiones 1643). Iris comenta de Santiván a partir de ese encuentro "su sensibilidad desarrollada entre ejemplares humanos de otra clase", agregando que "ha cometido una involuntaria torpeza de esas que crea la diferencia de medio social, que son inevitables" (Memorias 385). Pero las suspicacias de Santiván se esfumaron ante Iris, a quien sintió como "hermana de mi alma ... habría querido gritarte que te adoraba" (Citado por Iris, Memorias 390). Iris menciona reiteradamente la diferencia de clase de Santiván, en tanto este aspira a la asimilación total entre ambos, aunque Iris reconoce su necesidad intelectual de vínculo con destacados miembros de las clases medias, en los cuales aprecia una modernidad, frescura e inteligencia no habitual en la decadente aristocracia.

${ }^{13}$ El público del Ateneo "estaba constituido por jóvenes estudiantes con aspiraciones literarias, a los cuales se sumaban algunos profesores, políticos y literatos de cartel, además de 'numerosas familias de sociedad' ... que creían que era un 'deber moral de noblesse oblige el prestar el aliciente prestigioso de su presencia a estos recitales'”(Catalán 128). 
medias eran aún en Chile un sector sin una identidad política ni social propia: salvo excepciones, estaba "todo el tiempo huyendo de sí misma, tratando de incorporarse a la oligarquía. No pretendía transformarse en grupo alternativo a ella, aun cuando podía criticarla resentida, pero solapadamente" (Gazmuri 9 y 10).
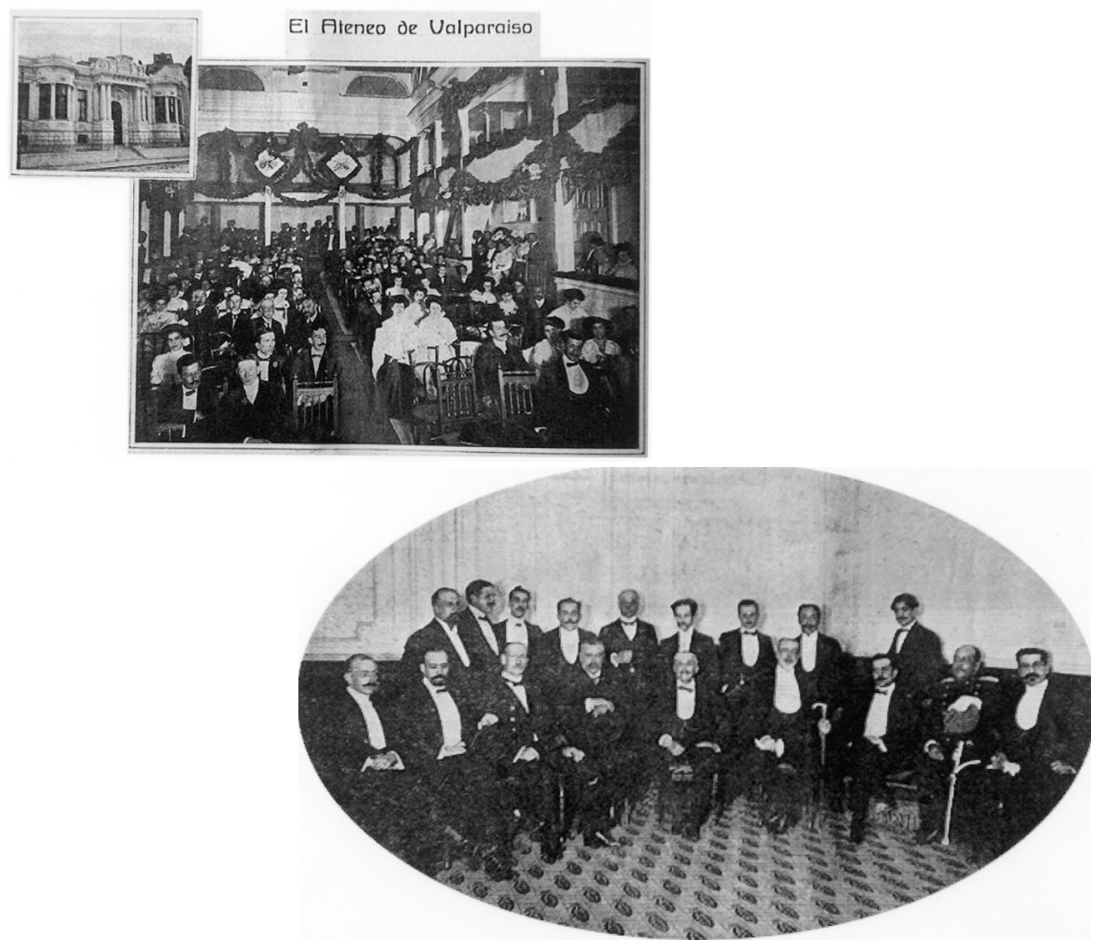

Público del Ateneo de Valparaíso con mujeres "de sociedad", y directiva solo masculina. En Zig Zag Nº 195 (15-11-1908).

En este contexto, la opción de la SAECH como organizadora de los Juegos Florales de 1914 fue clara: buscó un ambiente de boato y brillo social propio de la sensibilidad modernista, para lo cual incluyó en su performance solo a quienes mejor representaban los capitales dominantes dentro de "lo digno de ser visto", ya que graduaron la visibilidad de los sujetos según categorías de poder social cruzadas con las de género, según la belleza del cuerpo (femenino) y de la palabra (masculino) ${ }^{14}$. El cuerpo sobre

${ }^{14}$ El género y la clase tienen una instancia de construcción performativa: es en un habitus que se generan los conceptos de lo deseado, permitido y proscrito en los seres 
el escenario en estos Juegos Florales fue así un cuerpo sobre-significado y hecho metáfora desde su rol representacional elaborado dentro de la simbología activada en ellos, utilizándose a la Corte de Amor como estructuradora del ceremonial, símbolo de un particular concepto de poeta y de poesía.

Al constituir esta Corte se optó por un segmento de lo femenino identificado con la más alta expresión de la raza: las jóvenes de alta sociedad chilena, de estirpe aristocrática, asociadas con lo blanco caucásico y con el estrecho circuito de familias gobernantes ${ }^{15}$. El espacio seleccionado para la performance fue congruente con lo anterior: un teatro de palcos, el gran Teatro Santiago.

\section{POETAS Y ESCRITORES VS. LA CORTE DE AMOR: CONVOCATORIA EN CRUCES DE CLASE Y GÉNERO}

El llamado a adherir a los Juegos Florales de Santiago de 1914 fue realizado a través de un artículo de la escritora Roxane en Zig-Zag, en el que convocó a las mujeres "de sociedad" "para que "coronaran al poeta laureado", siendo esta una prioridad, puesto que solo al final del texto se mencionan los premios literarios y sus jurados. La estrategia para atraerlas fue posicionar los Juegos como expresión de la cultura chilena cosmopolita, en tanto serían equivalentes a los realizados "en otros países tan cultos como el nuestro".

La legitimidad de los participantes del ceremonial se distinguió en este texto según su género: lo masculino se representó con los "eminentes poetas chilenos" que organizan el concurso; lo femenino, con la Corte de Amor o "damas de alta alcurnia y a veces de estirpe real" que coronan a los poetas. Estos poetas serán así coronados por mujeres

humanos, en tanto los cuerpos realizan su coreografía ante espejos identitarios remitidos a pantallas idealizadas (Silverman). Estas determinan los cuerpos sustraídos a la mirada, aquellos sin posibilidad alguna de ser reflejados en ciertos espacios cívico-públicos en los que se define ceremonialmente "lo digno de ser visto" y "los modos de ver".

${ }^{15}$ En esta época finisecular dominada por el darwinismo social, "la idea de raza impregnó de modo tan potente los enunciados de verdad como la de progreso" (Hobsbawm 40). En las políticas de inmigración de europeos a Chile se negaba el componente indígena de su población para asimilarla al caucásico, sede de la civilización más desarrollada. "(La población chilena es) altamente homogénea, donde la raza blanca caucásica predomina casi sin excepción ... sólo un antropólogo profesional sería capaz de discernir huellas de linaje aborigen en las clases bajas" (Chilean Government 53).

${ }^{16} \mathrm{La}$ "sociedad" era un término que identificaba a la oligarquía. Según Krebs, El Mercurio en 1910 solo reconocía en sus páginas a dos grandes grupos sociales: la aristocracia y el pueblo, con total omisión de las clases medias, que no obstante, eran más numerosas pero carentes de visibilidad. Iris, refiriéndose al "buen tono aristocrático" vigente en 1902, afirma: "Casi no existía la clase media, de manera que componían la llamada sociedad las antiguas familias de rancio abolengo" (Memorias 157). 
que ya poseen corona ${ }^{17}$. Se pide el apoyo de la agraciada y benefactora "sociedad femenina" chilena para "alentar los esfuerzos de los que enaltecen la patria". Son, entonces, las bellas y aristocráticas mujeres el aliciente de los poetas chilenos, en tanto ellos son quienes enaltecen la patria, al igual que otros hombres lo hacen en el campo político o militar. Ellas están remitidas a ellos en relación personal; ellos al país en relación con lo público.

Fue más fácil echar a andar el concurso literario que la Corte de Amor, buscada con ahínco por los poetas de la SAECH en calidad de mecenas y ornato de la fiesta. Relata Santiván:

La Corte de Amor debía estar formada por las jovencitas más bellas de la sociedad santiaguina. Su concurrencia significaría un despliegue de lujo que costaría una fortuna a los padres de las agraciadas. ...fue necesario vencer dificultades innumerables. La mayoría de las niñas elegidas se negaban a participar en el magno concurso de arte, lujo y belleza si no se les aseguraba ocupar el trono. ...conseguimos que se aceptara un plebiscito y... resultó elegida reina la hermosa joven María Letelier del Campo, sobrina política del Presidente Pedro Montt (Confesiones, cit. en Catalán 130).

La Corte de Amor era "la guinda de la torta" de la belleza femenina y del poder social que se exhibiría en el teatro, y se logró que su Reina estuviera adscrita al poder político, al tener ella lo más cercano a una "corona" en una República: era pariente cercana de un prestigiado presidente de la Nación. Estas cualidades caracterizaron también al público, calificado según dos variables que expresaban el éxito de la convocatoria: todo él era "escogido" en términos sociales y, en cuanto al género, las mujeres eran "las más bellas" dentro de ese segmento ${ }^{18}$ :

${ }^{17}$ Se enfatiza que en los renombrados Juegos Florales de Cádiz de 1912, la hija del Presidente de Argentina coronó al poeta triunfante. Aún en la década de 1940, se sigue esta práctica: Carmen Franco, hija del general Franco, fue la Reina de la Corte de Amor de los Juegos Florales de Burgos, prosiguiendo la asociación entre poder social y legitimación del poeta en dicho ceremonial.

${ }^{18}$ La revista Zig-Zag corrobora esta calificación de "hermosa fiesta artística y social", valorando el mecenazgo gracioso de la "sociedad" a la literatura chilena al aportar sus mejores bellezas a la Corte de Amor, en un trueque entre cultura y prestigio social. Pero luego convierte esta fiesta en una metáfora de unidad social integradora de sus polos sociales, al producirse un "sentir colectivo -arriba y abajo- en favor de las bellas letras" (Zig-Zag 241: 26-12-1914). Ese "arriba y abajo", que ostensiblemente excluye "el medio", se remite a la par a una presencia dual de clase como a la ubicación en las segregadas aposentadurías del teatro (palcos y balcones vs. anfiteatro y galerías). El Mercurio (23-12-1914) también utiliza el término "público selecto" en términos sociales, al cual adiciona el calificativo de "culto" ("un público selecto y culto ocupaba las localidades del Santiago"), incluyendo así potencialmente a un público culto que no es de "sociedad" (¿mesocrático?) y viceversa. 
El acto se llevó a efecto con brillo extraordinario y público escogido que llenaba todas las aposentadurías del Teatro Santiago. Las damas más bellas de la ciudad, tanto en el proscenio como en los palcos y platea, lucían trajes vaporosos y deslumbrantes.

¿Por qué tanto interés en incluir como elemento central de los Juegos Florales la belleza de las mujeres, entendida como despliegue de lujo en palcos y plateas y en especial en el escenario, en su Corte de Amor? Para comprenderlo, habría que remitirse a la política del cuerpo vigente para la mujer de ese tiempo: la obligación de la belleza femenina. Lynn Hunt postula que "el vestido fue el terreno en el cual se jugaron tanto el género como la diferenciación política" tras la Revolución Francesa en el mundo occidental (189), lo que vincula a la cuestión de la exclusión de la mujer del espacio público; la inscripción del género en el cuerpo vestido habría sido estratégico en la construcción de los fundamentos civilizatorios de dicha sociedad "en esa ecuación moderna entre despliegue espectacular y subjetividad femenina" $(191)^{19}$. En la Época del Imperio, esta diferenciación entre belleza femenina/renunciación masculina habría llegado a su cúspide ${ }^{20}$. La obligación de la belleza femenina se exacerbaba en ciertas circunstancias, siendo una de las principales cuando asistían a un teatro de palcos como el Teatro Santiago, escogido por la SAECH como sede de estos Juegos Florales.

\section{EL TEATRO DE PALCOS: SÍMBOLO DE LA MODERNIDAD Y DEL DESARROLLO DE LA RAZA}

El espacio de realización de una performance es significativo en tanto todo espacio "ayuda a estructurar los eventos que tienen lugar en él" (Burke 108). En especial, los

${ }^{19}$ La Ilustración afianzó las teorías que distinguían al hombre y a la mujer, justificando la exclusión de la mujer del espacio público por argumentos biológicos (emotividad e intuición femenina versus razón masculina), lo que debía evidenciarse en su apariencia diferencial. Los hombres uniformaron sus vestimentas para no connotar con ella privilegios antidemocráticos, imponiendo el pantalón y la levita oscura, y delegaron en la mujer la obligación de la elegancia y la belleza, de la variedad imaginativa de su vestuario, transformándola en un objeto a ser mirado por el hombre y no viceversa (lo que la teoría psicoanalítica del cine ha tomado como el poner a la mujer en el encuadre del ojo de la cámara, identificado con el ojo controlador masculino).

20 "Cortesana o instalada, la mujer ya tiene un papel en el espacio público de la ciudad. ... Su primer poder es estético. En el espacio público, las mujeres casi tienen el deber de la belleza, que ejercen las princesas de las cortes europeas... La burguesía reproduce este modelo según una división de roles sexuales que delega en las mujeres la ostentación del lujo y del ocio. Hombres ocupados, atareados, vestidos de negro - solo los dandis se permiten el refinamiento de los accesorios- contrastan con mujeres ociosas y entregadas a una mundanidad tan frenética como ritualizada" (Perrot 24). 
urbanos, los cuales, imbricados con la matriz civilizatoria de cada época, son generados por, y generan, redes de usos asociados a lógicas de poder y a políticas del cuerpo (Sennett). Si desde la Conquista los españoles imprimieron en sus ciudades la impronta de una lógica racional del poder, al concebirlas como "núcleos expansivos de la civilización", ya bajo la hégira francesa en el siglo XIX, el paradigma fue "la construcción social del espacio conforme a criterios de clase" (Vicuña, La Belle 45 y 49). En esta línea, la intervención urbana de Santiago realizada por Vicuña Mackenna en la segunda mitad del siglo XIX, con el horizonte de convertirla en la "París de América", siguió el modelo parisién de Haussman ${ }^{21}$. ¿Qué representaba, así, la elección, por la directiva de la SAECH, del Teatro Santiago como sede de los Juegos Florales?

En la capital, se había acrecentado exponencialmente la infraestructura para realizar actos culturales, dada la nutrida actividad cívico-pública de esa época de capitalismo organizado. Y si en vez de un salón académico o uno gremial como solían utilizar los Ateneos para conferencias, recitales y premiaciones se eligió un teatro, que fuera el Santiago fue decidor, porque los más de treinta teatros disponibles tenían públicos orgánicos altamente diferenciados según clase social.

El Teatro Santiago, situado en la esquina de la elegante calle Dieciocho con la Alameda, surgió de la remodelación del Circo Trait realizada por Augusto y Eduardo Matte en 1886, según el modelo del teatro de palcos. El objetivo fue dar un marco adecuado a las presentaciones de la gran diva Sarah Bernhardt en Santiago, constituyéndose en sede complementaria al Teatro Municipal $^{22}$ en la incorporación de esta capital al moderno mercado cultural cosmopolita. Coincidentemente, para Hobsbawm, el indicador de que la irradiación de la civilización europea moderna se ha asentado en una localidad es que en ella funcionen dos instituciones: la universidad... y el espacio arquitectónico/social del teatro de palcos (o de ópera) $)^{23}$.

${ }^{21}$ Se higienizó la ciudad, expulsando a los pobres fuera de sus contornos, y se construyeron racionalmente avenidas, parques, plazas, monumentos, servicios públicos, de modo de hacer de ella un lugar "propio, la ciudad ilustrada, opulenta, cristiana" (Vicuña Mackenna Transformación 24-25). Los espacios urbanos perdieron su cualidad pluriclasista para seguir una lógica estamentaria según clase y capacidad económica (y también, según género, como los clubes solo para hombres), la que obviamente tenía sus flujos e intersticios, presionada por una realidad socio-económica diversa y en rápida expansión y desplazamiento de la oligarquía aún en el poder.

${ }^{22}$ El cual lucía sus galas en esplendor tras su reconstrucción en 1873 dentro del ya comentado proyecto modernizador de la ciudad, impulsado por Vicuña Mackenna.

23 'Determinadas instituciones tipificaban la zona de 'desarrollo' o de dominio europeo, fundamentalmente la secular institución de la universidad ... y por motivos diferentes, el teatro de ópera. Ambas instituciones reflejaban la penetración de la civilización 'occidental' dominante (en el tercer mundo)" (Hobsbawm 34). Estos teatros convocan al público local a partir de espectáculos de rico estímulo sensorial (ópera, teatro dramático, ballet, etc.), realizados directamente por compañías europeas o por artistas enraizados en Europa, por lo 
Este tipo de teatros, en esa su época de gloria durante la Belle Epoque, operaba como una ecuación simbólica de las estructuras y dinámicas de la sociedad y del arte burgués, existiendo estrictas normas respecto a quién ocupaba cada espacio, estando el público distribuido según capacidad económica, prestigio y género en palcos, balcones, sillones, plateas y galerías.

En efecto, una de las máximas presiones por "la obligación de la belleza femenina" se dio en los albores del siglo xx en el teatro de palcos, al elevarse durante la Belle Epoque los requerimientos para ellas en el espacio público, siendo este uno por excelencia: "Hoy día se exige mucho en una toilette de teatro; desde el peinado hasta el zapato debe ser como para ir á un baile" (Muguet). De aquí que las mujeres, entre otras cosas, iban a los teatros de palcos para ser vistas y para ver(se) in-corporadas en la moda ostentosa de la época, favorecidas por la costumbre de iluminar palcos y plateas durante la función, ocasionando el brillar de sus joyas.

Ellas debían ir solo a palcos y balcones, cuyo acceso era mediado por fuertes sumas de dinero, y cumplir allí la comentada "obligación de la belleza femenina". Hasta muy entrado el siglo XIX, si no podían hacerlo, debían ir a platea, "tapadas" con un manto que, ocultando su identidad social, les dejaba solo un ojo al descubierto, siendo Martina Barros la primera mujer que rompió con este tabú en el Teatro Santiago en 1886 (Hurtado, La tapada) ${ }^{24}$.

En estos palacios del arte de la elegancia como eran los teatros Municipal y Santiago, no cabían pobres o feas, ya que en ellos se alegorizaba el desarrollo de la raza, en cuya cúspide estaban el hombre blanco racional y la mujer blanca... y bella ${ }^{25}$. La fealdad, considerada un estigma psíquico, allí había que esconderla por "anormal" (Foucault), como se escondió a los pobres junto al Palacio de Bellas Artes en la fiesta del Centenario por no estar a la altura del desarrollo civilizatorio del país ${ }^{26}$. Esta práctica revela que la "sociedad" que asiste a estos teatros no quiere verse en el espejo de la fealdad ni en el de la miseria, ambos, quiebra-espejos de su pantalla deseante del sujeto ideal moderno, cuya apariencia era un signo de su desarrollo psíquico-espiritual y racial.

que son un vehículo de asentamiento de su hegemonía cultural. En Chile, los escenarios del Municipal y del Santiago, a la fecha eran ocupados, en sus espectáculos profesionales, preferentemente por compañías europeas en gira.

24 "Como entonces la clase media era muy pequeña e iba muy poco al teatro, en muchas de las representaciones de Sarah Bernhardt fui la única mujer en la platea” (Barros 151).

25 "Las diferencias entre los sexos, en lo que se refiere a la cavidad craneal, aumenta con el desarrollo de la raza, de modo que el hombre europeo es mucho más excelso que la mujer (europea), (a diferencia) que el negro respecto a la negra" (Darwin).

26 “¿Qué dirán - pregunta El Mercurio- los extranjeros que visitan el Palacio de Bellas Artes que se inauguró entonces (para las fiestas del Centenario) al ver, 50 o 60 metros más allá del magnífico Palacio los ranchos más miserables, gente andrajosa, pordioseros, niños semi desnudos?" (citado en Krebs 34). 
No podía sino estar enterada de esto Gabriela Mistral, ya que en la prensa y en la literatura locales se propulsaba en estas latitudes la valoración del refinamiento en el vestir como un "producto exquisito de una civilización ya superior y madura" (Wanderer), como un momento de arte. Fernando Santiván, el principal organizador de estos Juegos Florales, sostenía en 1912, en el mismo semanario en que solía publicar Gabriela, que la principal tarea femenina era agradar al hombre, para lo cual debía transformar su cuerpo con medios artificiales para proyectar en él la belleza de su alma:

La mujer es artista de raza, ni más ni menos que un escritor ó un músico de profesión. Ellos modelan hermosos bustos en yeso ó en mármol... La mujer, en cambio, hace de su cuerpo ... una obra de singular belleza. ... La moda femenina es el molde, el vaso ... que construye toda alma de mujer para mostrarse en toda su poderosa seducción (La moda).

Ser artista en su propio cuerpo -único modo de ser artista para la mujer-, solo era posible cuando se había in-corporado este saber desde el habitus: era cuestión de estirpe, sensibilidad y ojos educados a través de una larga sociabilidad. Si Santiván estratifica a la mujer según estos criterios, seguro que no quiere ver aparecer en el escenario de sus Juegos Florales, ese concurso "de arte, lujo y belleza", a una que no sea "una magnífica flor", según concluye en su ensayo sobre la moda femenina:

El arte ...tiene también su aristocracia, su clase media y su bajo pueblo. ... la mujer de poco espíritu, por mucho que se atavíe, no pasará jamás de ser sino una obra mediocre ... mientras la otra se desplegaría ante Ud. como una magnifica flor ... usando del arte de vestir como un simple medio para producir belleza.

Porque la distinción de géneros era tajante en ese Coliseo, según explicita Santiván en sus Confesiones al describir al Teatro Santiago esa noche: "todas" ellas son las "más bellas" de los círculos sociales "escogidos", ataviadas en trajes vaporosos y esplendentes, mientras los hombres, en sobrio traje de etiqueta, se cualifican según su posición de poder en el espacio público: "escritores, hombres de gobierno, militares". Son los detentores de los poderes de la palabra (del logos) y de las armas.

\section{LA SIMBOLOGÍA MODERNISTA DE LA MUJER-FLOR Y DE LA FLOR NATURAL}

El rescate de los Juegos Florales en esta época es congruente con que la flor haya sido un elemento omnipresente en esa Belle Epoque, un significante investido por deseos y proyecciones diversas. En una cultura que se goza en el adorno y en la belleza, en el artificioso toque que cita lo natural, la flor natural fue la primera invitada para engalanar teatros y banquetes, para construir figuras alegóricas, para ser lanzada sacrificialmente en corsos de flores, para adornar profusamente el cuerpo y el cabello de la mujer. Cuando los Juegos Florales ofrecen una Flor Natural como premio principal del certamen, ¿qué están ofreciendo? 
Como palabra, "flor" fue una figura manida para nombrar a la mujer: la prensa chilena de entonces abunda en "flores vendiendo flores" al referirse a floristas, "un bouquet de flores" para nombrar a un grupo de niñas, "flor en medio de las flores" para evocar a una mujer en un campo florido. También fue un tropos poético, del cual destaco dos tipos de elaboraciones, no siendo casual cuál de ellos adopta los Juegos Florales chilenos del 14. Uno, el del Baudelaire de Las flores del mal, siendo esas flores las mujeres puestas en el abismo de una sexualidad enrarecida y sensualista, trágica y envolvente, decadente y desesperanzada. La mujer lesbiana, la prostituta, la amante ocasional, la compañera nocturna de la bohemia y del bar. Flor de un día, bellezas y placeres efímeros, carnalidad condenada a la corrupción. A la par, el símbolo del Art Nouveau, arte dominante en la Belle Epoque, era la mujer-flor, mujer sensual que mira de frente. Ecotada, su cuerpo es como un tallo de flor, el que ciñe con velos, envolvente como serpiente ${ }^{27}$.

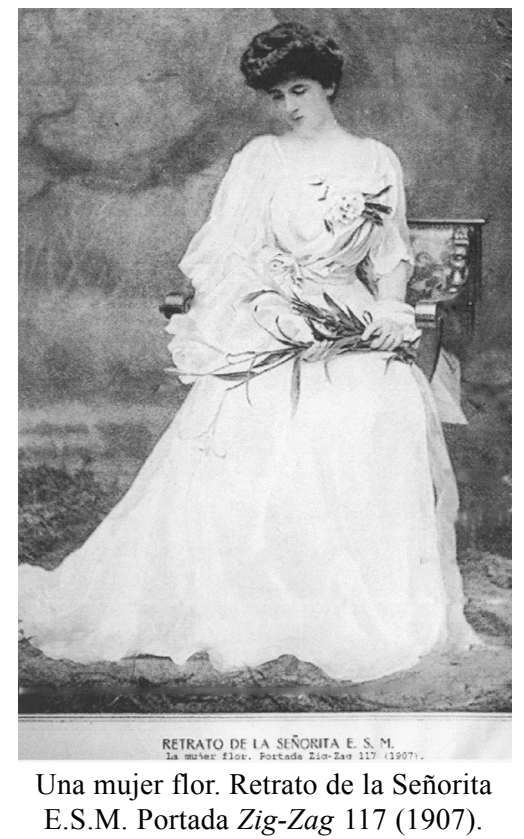

Cuando se equivale mujer a flor en el imaginario chileno, no son estas elaboraciones transgresoras de lo femenino victoriano las que salen a colación, sino las de una sensibilidad tardorromántica que trata "a la naturaleza como paisaje del alma": este "espiritualismo de vanguardia"(Subercaseaux 63) hace participar a la flor como contraste y complemento del boato palaciego, y sustrae a la mujer de la oligarquía del despliegue de riquezas en las que de hecho circula. Ese gran moderno que fue Vicuña Mackenna lo expresó cabalmente: "¿Véis aquellas dos niñas frescas, ligeras, de ojos brillantes y dulces ...? Son dos botones de rosa que se abren en el mismo tallo. .... ¿Y aquella beldad de pálido rostro...? Es el lirio de la vega que se estremece sobre su esbelto mimbre... y envía con él su perfume al cielo" (El baile).

Con frecuencia, los hombres de letras locales ubicaban el nacimiento de lo femenino en el mito, en la antigüedad griega

${ }^{27}$ Dos actrices fueron su ícono: Loie Fuller con el baile Serpentina, en el cual ondulaba su túnica contrastada con cientos de focos lumínicos para convertirse en cambiantes flores. La otra fue Sarah Bernhardt (1844-1923): "por su talento y belleza, encarna a la mujer-flor del Art Nouveau, mujer esfinge, rodeada de animales exóticos, atractiva e inaccesible, que ejerce su seducción como un poder" (Perrot 28). 
legitimadora de idealizaciones, de lirismos que reiteran la imagen del cuerpo femenino como flor y la de su naturaleza como hundida en el misterio: "Es Afrodita naciendo... No hai nada mas gracioso que la figura de esa joven mujer surjiendo como una flor desde el fondo de un misterio" (Mont-Calm). Las mujeres de la época lo reafirman en el recurso metonímico de poner una flor natural sobre su cuerpo, vestido, cabellos o en sus manos, y luego retratarse o fotografiarse con ella para dejar fluir de una en otra sus cualidades y bellezas.

La flor, entonces, como mecanismo de desmaterialización del referente mujer: llevada a un terreno de lo etéreo y espiritual, ella es flor delicada y misteriosa, es encantamiento y fantasía. Pura naturaleza, está más allá de afanes de poder o posesión; no tiene arraigos mundanos, no habita la terrenalidad de lo contingente ni de lo interesado ni la pesadez del materialismo. No compite por el poder ni opera en el espacio cívicopúblico o público. Está en la esfera del silencio, no en el del logos. Y, dentro de la lógica que constituye la performance de los Juegos Florales, la Flor Natural se materializa escénicamente en la Reina de los Juegos, elegida por el poeta triunfante de entre las jovencitas que integran la Corte de Amor.

\section{LA PERFORMANCE DE LOS JUEGOS FLORALES REALIZADA EN EL TEATRO SANTIAGO EN 1914}

En la reconstrucción de la performance de los Juegos Florales de 1914 en Santiago, ocuparé como principal referente textual el relato "La noche de los juegos florales", de Xavier de Lys (¿seudónimo?), organizado según una clásica estructura dramática que captura la atención del lector mediante un creciente suspenso que lo involucra emocionalmente, aderezado con rebuscados adjetivos propios del léxico modernista ${ }^{28}$.

\section{· Situación INICIAL: El JUEGo DEL DESEO EN LA PLATEA}

Noche de "luz, palmas, sonrisas, ojos radiantes...". El baile de los ojos se consigna como la acción principal realizada dentro del teatro; su destino focal, las lindas mujeres jóvenes envueltas en el juego amoroso masculino.

Bellos rostros bañados por el plenilunio de las miradas amantes. Senos núbiles estremecidos casta y dulcemente bajo la suavidad vaporosa de las sederías y la rutilación cambiante de las piedras deslumbradoras. La gran sala naufragando en turbadoras irradiaciones, semejantes a la nave solemne de un templo de Misterio, donde los Trovadores hubieran dado cita amante a la caravana de sus versos. Ante el pórtico, piafar de pura sangre

${ }^{28}$ En lo que sigue, las citas entre comillas se remiten a este mismo texto. Este lo complementaré con información proveniente de El Mercurio del día siguiente (23-12-1914) y de la revista Zig-Zag (26-12-1914). 
i trepidaciones de lustrosos automóviles. Era la noche sagrada de los poetas.

Reina la gozosa inmersión en la materialidad provista por el dinero gastado sacrificialmente en sedas, joyas, tules, automóviles lustrosos, carruajes y caballos fina sangre según la "fijación objetual hedonista Belle Epoque" (Subercaseaux 64). Las mujeres: vaporosas, modestia casta en ropajes de costosa y cuidada elegancia, exhiben su artificiosa naturalidad. Ellas son flores, "jardín temblante”, cuerpos que emanan lo indefinible, más allá del lenguaje simbólico.

El poeta es el Trovador que en sus versos canta a la mujer y de ellos brota el Misterio que hay en ellas (ambos calificativos del género signados con mayúsculas). Él es el sujeto activo, el que entabla con ella un baile de miradas y descubrimientos, especialmente, con la mujer virginal indefinible. Con la Flor Natural. Esta definición del poeta lo ubica en juego inter-subjetivo de relación amorosa heterosexual. La una es de belleza corporal y suntuosa, cuyo interior está pudorosamente oculto; el otro acata la "renunciación masculina" a la belleza corporal, siendo activo en la elaboración del lenguaje simbólico: la palabra, en versos capaces de convocar al Misterio gracias a su amorosa inspiración en la mujer. En este esquema, ¿dónde cabe la poetisa?

\section{- FANFARria MUSicAl PARA RESALTAR El CUERPo DEL PODER POLÍtico}

El primer momento de solemnidad ritual en esta ceremonia es la interpretación de la Canción Nacional por una espléndida orquesta, a la llegada del Presidente de la República, Ramón Barros Luco. Estos Juegos Florales se ratifican así como un acto de la cultura oficial, identificado con el gobierno oligárquico, otorgando carácter nacional al certamen. La performance corporiza la organicidad de esta sociedad de escritores con el poder dominante, sin interés por establecerla con otras fuerzas vivas de la sociedad (lo popular, el proletariado, el anarquismo...) o por marcar la autonomía del arte respecto a lo político y a lo social.

Luego, la orquesta ejecuta la obertura de Guillermo Tell, de Gioacchino Rossini ${ }^{29}$, compositor romántico vigente en las veladas de ópera de los grandes teatros de palcos de Chile y del mundo, sumándose así la del Santiago al ambiente cosmopolita que los caracteriza.

\section{- La Corte de Amor al centro de la escena}

Tras alzarse aparatosamente la cortina del escenario, queda a la vista "la escena del trono". La escenografía compone "un salón rejio de columnas corintias, trasunto de la tradición del Arte i de los tiempos", en una evocación estereotipada de lo clásico griego. Al centro destaca el elemento principal: un trono cubierto de piel de armiño, símbolo de

${ }^{29}$ Información consignada en El Mercurio. 
realeza, elevado sobre altas escalinatas y salpicado de abundantes rosas naturales, según se aprecia en las fotografías. Alrededor de él, como "alas de luz y de gracia", cual hadas $^{30}$, las diez jóvenes aristócratas que componen la Corte de Amor. A la izquierda, los instrumentos musicales (piano y violín) y sus intérpretes. A la derecha, los cuatro poetas "vencedores en la justa florida" en el rubro poesía; junto a ellos, el Alcalde de Santiago y miembros de la SAECH. Ausente a la vista pública Gabriela Mistral, presencia anónima entre el público del anfiteatro o de la galería ${ }^{31}$.

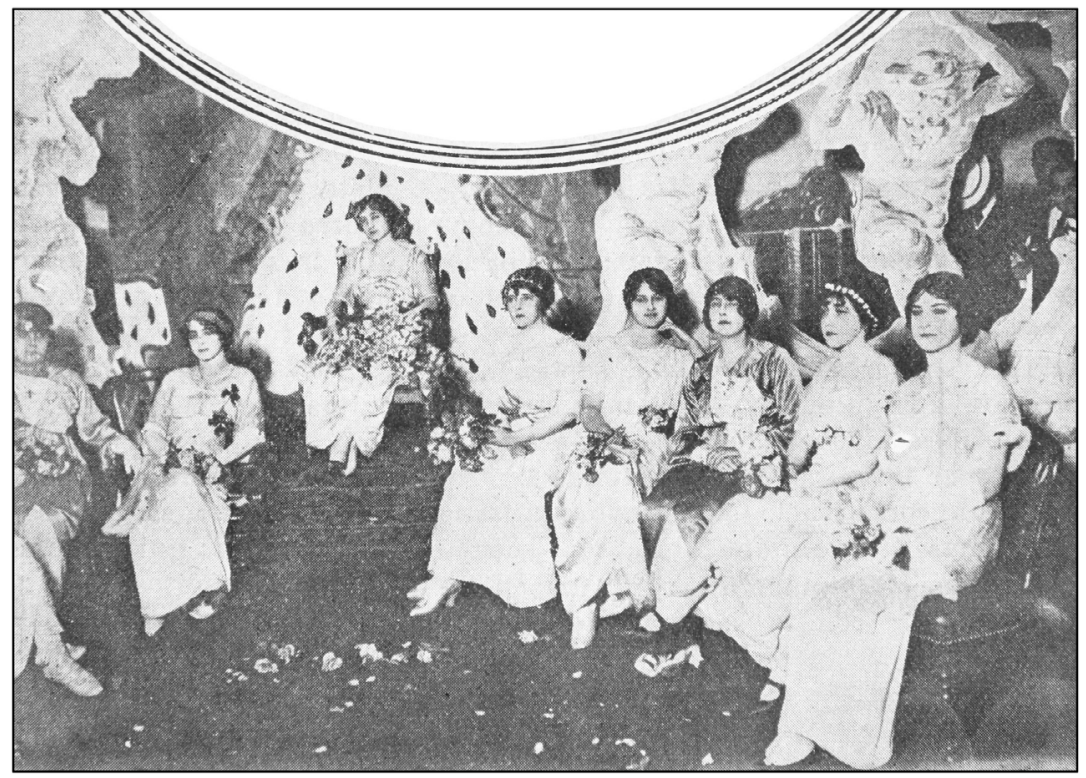

Corte de Amor de los Juegos Florales de 1914. En Zig-Zag 514 (26-12-1914).

${ }^{30}$ En los corsos de flores, las jóvenes que animan el concurso son llamadas "hadas de amor".

${ }^{31}$ Gabriela Mistral asistió de modo anónimo a este acto, y justifica este proceder en términos amorosos en carta a Magallanes Moure al día siguiente: "Fui solo por oírlo. No por oír mis versos (los había escuchado leer); no por aquello de los aplausos de una multitud (unos momentos sólo entre la multitud me hacen daño); por oírlo a Ud., por eso fui" (Cartas 23). Colijo que estuvo en el anfiteatro o en la galería por tener estos en el Teatro Santiago un precio cinco veces inferior al de los palcos, menor visibilidad dentro de la mirada panóptica mutua entre los espectadores y menor exigencia en cuanto a vestuario, arreglo personal y sociabilidad. 
Las personas en el escenario se distribuyen en perfecto equilibrio visual según sexo: un músico hombre y una músico mujer; diez mujeres de la Corte de Amor y diez hombres -poetas galardonados, escritores de la SAECH y autoridades políticas. Diez mujeres de vaporoso blanco dan cuenta de la belleza del alto rango social; diez hombres de estricta etiqueta negra dan cuenta del poder en la sociedad el espacio público (intelectual y político).

\section{- El clímax: la pareja ideal, la Dama y el Trovador}

Siguió el discurso de Ismael Valdés Vergara, Alcalde de Santiago, tras el cual el Presidente del Jurado, el poeta M. L. Rocuant, proclamó a los poetas premiados, mientras "sonoras salvas de aplausos saludan los nombres de los vencedores". Pero este no era el momento más esperado: el trono de "su Majestad la Reina de la Fiesta" aún estaba vacío. “Cuál será la elegida... mediante el veredicto mágico del Poeta Elegido?” El clímax de la performance fue de hecho el ceremonial del trovador triunfante en relación a la Reina:

Julio Munizaga Ossandón surje al frente de la escena i en nombre del Arte i la Belleza, proclama Reina de la Fiesta a María Letelier del Campo. ... El teatro en masa se alza. Resuena una marcha triunfal i bajo sus acordes unidos al glorioso aleteo de un aplauso inmenso, el trovador tiende la diestra enguantada de blanco a la mano de lirio de la Reina i la conduce hasta el Trono.

En este momento culmina la construcción del cuadro alegórico, se consuma la simbología: "En homenaje de sus sentimientos i tributo simbólico de su lealtad de vasallaje, el bardo pone en las manos de su Reina un búcaro de rosas, de adelfas i de mirtas" 32 .

¿Podía una mujer, dentro de este ritual de esquema heterosexual, proclamar a otra mujer como reina de la fiesta, reconociendo en ella al Arte y la Belleza? ¿Podía ofrecer su mano enguantada a la "mano de lirio" de la elegida y llevarla con toda apostura a los pies del trono, para luego ayudarla a subir la escalinata sin soltarle aún la mano? ¿Podía una mujer ofrecer "tributo simbólico de vasallaje" a la reina, ser un bardo que canta al amor de esta? ¿Podía ella luego ofrecer flores gentiles y refinadas a la reina de la fiesta, para sobresignificar la calidad de mujer-flor de esta (y no de sí misma)?

${ }^{32}$ Adendum: por cierto esta performance, en el perfecto sentido de la palabra, fue dos veces realizada: todo estaba ensayado. No fue Munizaga quien, cautivado por su presencia, eligió a María Letelier sino, como indiqué, fue elegida en plebiscito previo. María, ya advertida, usó un vestido con larga cola, el cual se extendió con majestad sobre las escalinatas en su ascenso al trono. La performance pública nunca reconoció esto, asumiendo que el rito estaba siendo consumado en el instante presente del acto, tal como lo requiere todo ritual en lo hondo de su sentido sagrado. 
Lo que esta performance realiza es entregarle al ganador del Primer Premio del Concurso, de la Flor Natural, su verdadera flor natural; pone a disposición del poeta la Corte de Amor, compuesta por las más bellas y ricas mujeres del reino, con el derecho a elegir a la que más lo seduzca. Ya elegida, puede el poeta decir sus versos bajo la inspiración de sus cualidades de mujer-flor y, para perpetuar esa creatividad, le jura lealtad y fidelidad en seguir cantándole sus versos, mientras ella siga siendo esa flor pura que ahora está ante él.

La Reina de la Fiesta y el trovador que la ha ganado en tanto Flor Natural satisfacen la máxima darwiniana del mejor ensamblaje hombre-mujer para el perfeccionamiento de la raza blanca: se elegirán como pareja la mujer más bella en su pureza y el hombre triunfador, ese que dirime su valía en algún terreno de poder masculino, y sale victorioso. El apareamiento de parejas así formadas a través de las generaciones habría resultado en la mayor belleza de la mujer de raza blanca y en el mayor saber y evolución cerebral del hombre caucásico, en comparación con todas las demás razas ${ }^{33}$. Por eso, al celebrar en los Juegos Florales a la pareja ganadora, cada cual el mejor en su ámbito de competencia genérica, se celebra implícitamente el progreso de la raza y de la civilización de la Nación.

\section{- Explicitación de la simbología de los Juegos Florales y de su Corte de Amor}

Prosiguiendo el ceremonial, el poeta Víctor Domingo Silva, Mantenedor de los Juegos, historia "estas justas de arte i de belleza, hija de esa Edad Media... bajo la mano proficua de Clemencia Isaura, con la divisa tres veces tentadora de Fé, Patria y Amor" y explicita la simbología de los Juegos Florales y de su Corte de Amor:

cuadro feérico en que se ve al Arte -principio de leyenda-transformarse i levantar el vuelo al golpe májico de la varita de la virtud: la Dulce Encantadora de todas las leyendas sois esta noche vos, es Vuestra Beldad, joh divina Reina de la Fiesta! Hadas maravillosas sois también vosotras, joh deliciosas damas de su Corte de Amor!

Silva, en este contexto de recuperación/reconstrucción de un cierto imaginario de los Juegos Florales, enfatiza que el Arte y la Poesía residen en "Vuestra Beldad Reina de la Fiesta", hada que con el poder de su varita anima a los poetas que le cantan su amor. Con ello, declara abiertos los Juegos y justifica cada premio, mientras el "heraldo del torneo" anuncia a cada poeta. Estos, a su vez, leen sus versos en dirección a sus

33 "Entre los animales, una hembra pasiva selecciona como pareja a los machos más agresivos o más atractivos, los con plumas más magníficas, los más melodiosos"; machos y hembras difieren en estructura por una continua selección de este tipo, la que en el ser humano ha causado que "ambos sexos se diferencien tanto en cuerpo como en mente", en la raza blanca, haciendo al hombre más excelso (Darwin 96-97). 
inspiradoras y galardones corporizados, la Reina y su Corte de Amor. Los Sonetos de la muerte de la triunfadora ausente, Gabriela Mistral, son leídos por Víctor Domingo Silva, respetando así la diferenciación genérica establecida. Todos los ganadores son luego coronados con coronas de laureles, salvo el (la) ganador(a) de la Flor Natural, quien recibe una flor natural de manos de la Reina de los Juegos ${ }^{34}$. Concluye la premiación con una apoteosis musical ${ }^{35}$.

Lo que no pudo faltar tras este momento de espectacularidad performativa moderna fue la sesión de fotografías de los ganadores y celebridades públicas rodeando en el escenario a la Reina de la Fiesta; quedó así plasmada para la memoria histórica la imagen de la Reina con su verdadera Corte de Amor: la masculina, la de los poetas laureados.

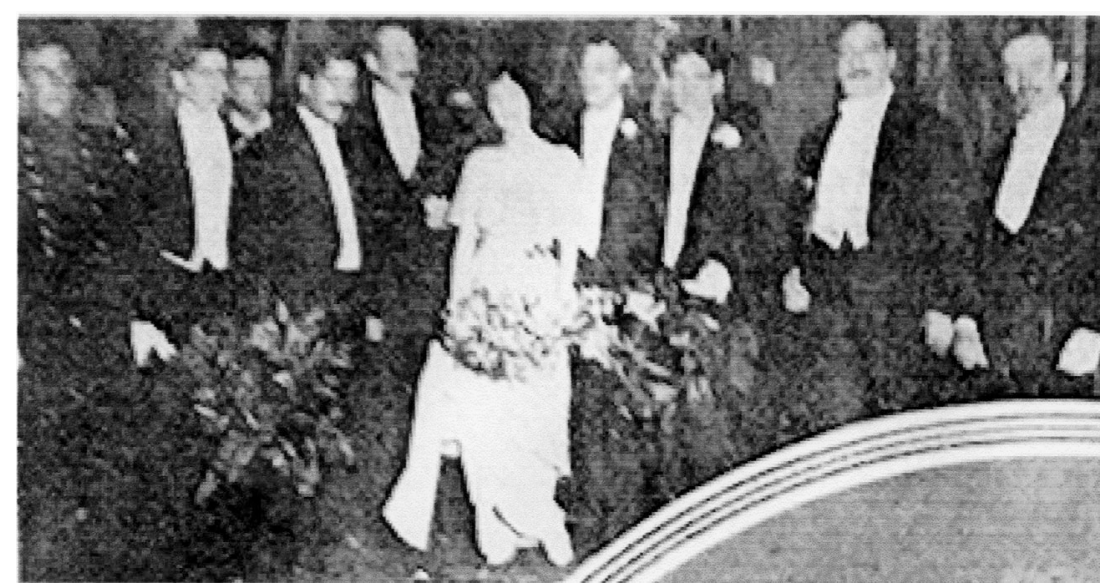

María Letelier del Campo, la Flor Natural, con su verdadera Corte de Amor: los poetas galardonados y de la SAECH. En Zig-Zag 514 (26-12-1914).

Nadie reparó entonces en que la tradición medieval de la Corte de Amor, que aquí se cita como referente, otorga a la mujer un rol protagónico en un sentido diferente al

${ }^{34}$ Víctor Domingo Silva recibió la flor natural en representación de Gabriela Mistral. Además, recibieron premios materiales: la Mistral, una "magnífica moneda de oro" aportada por la Municipalidad de Santiago, los otros ganadores, "objetos de arte" y otros obsequios.

${ }^{35}$ En la segunda parte del acto, se representa la obra ganadora del certamen "comedia", El rey consorte, del dramaturgo Pedro Gil. Aunque no he logrado acceder a este texto, su título evoca a un hombre gobernado por su esposa, recogiendo la temática recurrente de la crisis provocada por mujeres (modernas) que asumen una identidad de género "masculina" (Hurtado, Teatro), lo que no deja de ser irónico en este contexto. 
de su pura visibilidad corporal: en tanto literata e intelectual apreciada, la mujer ocupaba el centro de este ritual mediante el ejercicio de su palabra aguda, de juicio valorativo acertado, argumentaciones y razones expertas y sensitivas en torno a paradojas y enigmas del amor cortés (Pernoud 121-126). En cambio, en estos Juegos Florales de Santiago, no sonó nunca en público, audiblemente, la voz emitida por una garganta de mujer, y gestualmente fue más receptora que animadora de acciones.

\section{LA CARACTERIZACIÓN REALIZADA DE GABRIELA MISTRAL, GANADORA DE HECHO DE LA FLOR NATURAL}

La ausencia de la Mistral en ese feérico escenario fue justificada por Silva, comparándola con la poetisa italiana Ada Negri, ambas, maestras de enseñanza pública: "la excesiva actividad de las labores escolares al final del año, pero más que todo la excesiva modestia de su carácter" le impidieron ocupar "el sitio de honor que debiera junto a Su Beldad la Reina de la Fiesta i entre la pléyade esplendorosa de su Corte de Amor".

El lugar que se le habría asignado en el escenario, el lugar que habría "debido ocupar" la Mistral en caso de haber asistido, era en medio de la pléyade "esplendorosa" de mujeres de la Corte de Amor y no en medio de los poetas ganadores, primando su adscripción de género y no la de su quehacer poético creativo, no admitido como prioritario en ella. Pero allí tampoco cabía; en la performance realizada solo era posible una reina ( $\mathrm{Su}$ Beldad de alta estirpe enmarcada por su equivalente Corte de Amor) para un hombre (trovador que se tributa a ella) dentro del esquema binario de género en tensión de atracción amorosa y de poderes sociales. La caracterización que se hace de la Mistral: maestra pública, excesivas labores, modestia (de carácter) con el implícito de modestia también económica, deja en claro que ella no es una reina en flor según el concepto Belle Epoque: reina es la bella en espíritu/cuerpo, sin preocupaciones materiales ni menos con un trabajo remunerado, mujer que da la cara y el cuerpo en público según el principio de "la publicidad representativa" cortesana. El traje adecuado para haberse presentado como mujer hubiera sido uno "vaporoso y deslumbrante", como el que lucieron, según palabras de Santiván, "todas" las mujeres presentes en platea y escenario en ese lujoso acto. Ella, la Mistral, en cambio, según las fotos de la época, solía ocupar trajes oscuros, de tela gruesa, victorianamente modestos, enmarcando su rostro con un peinado sencillo. Quizás por eso, ha proliferado la idea de que no asistió precisamente porque "no tenía el traje adecuado"36.

${ }^{36}$ El Mercurio recientemente (Revista Ya, 15-12-1998), en un reportaje a las fotos emblemáticas publicadas por este diario a través del último siglo, elige de la Mistral una en que aparece en serio vestido negro (se reproduce en este artículo), la que habría sido publicada con ocasión de los Juegos Florales, explicando su inasistencia con el siguiente pie de foto: "Ella no tenía el traje adecuado", publicación que no he podido confirmar al revisar las ediciones de ese diario de fines de diciembre 1914 y enero 1915. Esta misma idea se recoge en otros textos en que se alude a su no presentación pública en los Juegos, utilizando incluso 


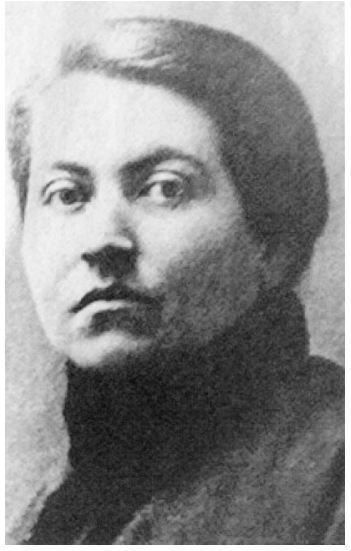

Gabriela Mistral hacia 1914. En Revista Ya, El Mercurio (15-12-1998).

¿Es posible imaginar a la sincera y físicamente recatada Gabriela Mistral modelando su busto, cintura y caderas con corsets y rellenos varios, en modas de disimulo con ruedos y enaguas, utilizando postizos en el pelo y maquillaje para aparecer "bella", para seducir al hombre a través del cuerpo, como requiere Santiván a las verdaderas mujeres "artistas": las de su propio cuerpo? Más aún, ¿hacerlo en completa exposición arriba de un fastuoso escenario a la vista de cientos de hombres y mujeres con pretendido saber, por estirpe y clase, de este arte, estando codo a codo con las más excelsas bellezas locales, las jovencitas aristócratas de la Corte de Amor?

$\mathrm{Su}$ triunfo como ganadora de la Flor Natural fue sin duda inesperado, y chocó con el esquema performativo de los Juegos ideado por la SAECH; por tanto, quebró la noción que los propios escritores oficiales de Chile tenían sobre su práctica y oficio. Introdujo un signo de alerta acerca de la conformación del campo cultural intelectual y artístico nacional y sus cultores de excelencia: ¿habría que admitir que una mujer ocupe ese lugar de excelencia? ${ }^{37}$ ¿Y que lo sea una mujer proveniente ya no de la aristocracia, o de las a veces admitidas clases medias, sino una con marca de clase/etnia ignorada y negada por las clases dominantes: una mujer de ascendencia campesina de rasgos indígenas ${ }^{38}$.

En todo caso, hubo quienes resintieron el descalce existente entre la identidad social de Gabriela y su participación en este concurso/performance signado por las marcas esplendentes y exhibitorias de la parafernalia modernista Belle Epoque: días

comillas, aunque sin confirmar fuente: "Gabriela no se presentó a leer sus propios versos, como hicieron los demás, porque "no tenía cómo hacerlo en forma digna"”. (http:// www.profesorenlinea.cl/biografías/mistralgabriela.html).

${ }^{37}$ Al menos la ovación con que la concurrencia, según El Mercurio (23-12-1914), saludó el nombre de la triunfadora indica que en la sociedad (¿femenina?) se estaban agenciando corrientes de opinión favorables al protagonismo de la mujer en la literatura o, al menos, en la poesía, aun cuando la utilización del seudónimo impidiera en ese momento conocer aún su identidad y raigambre social.

${ }^{38}$ Iris la caracteriza en su descripción física como teniendo un rostro "de máscara indígena" (Memorias 534), aunque cuando lo hace (1925), tras el regreso triunfal de México de la Mistral y la caída de los gobiernos oligárquicos, este término tiene un cariz positivo. A su vez, la propia Mistral le habría dicho al escritor peruano Alegría "Ciro, yo soy india” (Alegría 12). 
después de realizados los Juegos Florales, recibió un anónimo (¿proveniente de circuitos subalternos mesocráticos, obreros, de estudiantes?) que la acusaba de "farsante" por este hecho. Confesó a Magallanes que este enjuiciamiento la hirió en lo hondo, porque "nada he cuidado más celosamente que de ser presuntuosa y me he arrancado con pinzas calientes las pequeñas vanidades" (Cartas 30).

\section{¿TODAS ÍBAMOS A SER REINAS? EL HOMENAJE LÍRICO DE LA MISTRAL A LAAUTÉNTICA FLOR NATURAL}

El corolario de los Juegos Florales se prolongó durante un mes, ahora por escrito en un álbum de poemas abierto en Homenaje Lírico a su Majestad la Reina de la Fiesta, Srta. María Letelier ${ }^{39}$. Lo inician dos dedicatorias escritas por su pareja ideal, el poeta triunfante Julio Munizaga Ossandón, quien simuló elegirla Reina de los Juegos y la condujo al trono/altar de la Corte de Amor. Le siguen dos poemas de quien no tuvo cabida en esa performance, Gabriela Mistral y, a continuación, los de casi todos los poetas chilenos del momento ${ }^{40}$.

En los poemas de los poetas varones se advierte una majadera reiteración de los elementos vulgarmente asociados al amor cortesano medieval, identificando a la amada con la Madona celestial e insistiendo en su construcción de género como mujerflor, virgen y doliente, bella en su modestia, silenciosa, en tanto la autodefinición del poeta adscribe a lo tardorromántico, ya que dicen extraer su inspiración de esta musa nocturna y pálida ${ }^{41}$ : "En estado de vigilia, el poeta espera la manifestación de las musas... Todavía estamos en el período de la inspiración, cuando el poeta famélico requiere alguna forma de soplo divino para entonar sus salmos" (Vicuña, El París 67). No es cualquier soplo divino el que esperan: según la definición genérica y social actualizada en estos Juegos santiaguinos, esa musa es una joven aristocrática bella y refinada en vestuario, expresión de su interior excelso, a quien se contempla y adora pero a quien nunca se le oye proferir palabra. Ni menos, poemas: él los hará por ella ${ }^{42}$.

${ }^{39}$ Estos aparecen transcritos y reproducidos en El libro de los juegos florales.

${ }^{40}$ Carlos Barella, Ángel Cruchaga Santa María, Daniel de la Vega, Juan Guzmán Cruchaga, Jorge Hübner, Vicente Huidobro, Max Jara, Carlos Mondaca, Manuel Magallanes Moure, Claudio de Alas, etc. Aparte de la Mistral, solo otra mujer escribió en él: Luisa Anabalón, bajo el hiperbólico seudónimo de Juana Inés de la Cruz -el cual cambió por Winétt de Rokha tras su matrimonio con el poeta Pablo de Rokha.

${ }^{41}$ Julio Munizaga da la pauta con Oblación -"ofrenda y sacrificio que se hace a dios", según la RAE-, dedicado a "la más bella de las reinas" en su calidad de "paje poeta" y "paje trovero".

42 Jorge Hübner explicita esta dualidad: María Letelier contiene la poesía, sin poder articularla: necesita al hombre, poseedor del poder del lenguaje, para que esa palabra hondamente oculta en ella pueda aflorar. Hübner pide al poeta que llegue al corazón de esta reina "publicad sus poesías. Nadie las ha visto. Será entonces cuando, en la lengua de los vasallos, llegue a todas las almas su imperio de gracia". 
¿En qué posición se ubica Gabriela Mistral al hacerse presente con la palabra -el soneto Con su retrato- frente a María Letelier, la verdadera Reina de los Juegos Florales, esa Flor Natural que debió haber sido su premio si ella hubiese sido un poeta y no una poetisa, y con la cual no quiso calibrarse cuerpo a cuerpo en esa performance feérica del Teatro Santiago?

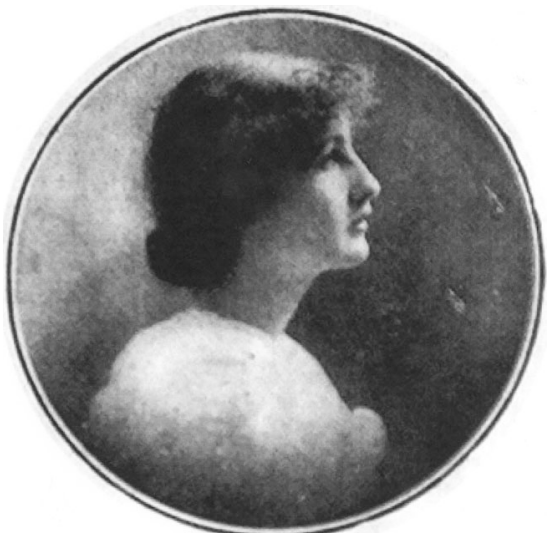

Retrato de María Letelier del Campo. En El Mercurio (23-12-1914).

Desde el título, Gabriela deja en claro la distancia infranqueable existente entre ambas; su poema se basa en el retrato de la Reina, en su imagen plasmada en el papel ${ }^{43}$. Ubica a la mujer del retrato en un locus inalcanzable, al hacer de ella una alegoría de lo celestial, un ideal brotado de imágenes de flores de pureza virginal (azucena, lirio). Pero, a diferencia de lo realizado por los poetas mencionados, este ideal está encapsulado en un cuerpo de formas concretas, las que, mediante reiterados oximorons, tornan su pasional intensidad en frialdad. Reside la reina en mundos lejanos de naturaleza celeste y luminosa: en país de lunas llenas, pero es ella nevada de azucenas: fría belleza en corazón de lirio y alma apasionada que

vuela en canción. Su infancia fue, por el contrario, diurna, nacida en los trigales de sol en el erial del Señor. Su figura esbelta de lágrima de nieve de nuevo se congela en transparencia evanescente. Su interior es líquido: licor (ardiente) pero azul (frío, de sangre azul) y brilla como las estrellas (nocturnas) y, más que ojos abiertos al mundo, tiene párpado de flor (un suave cerrar de ojos).

Es reina con mayúsculas, de una casta no terrena. Reitera luego la Mistral lo de la casta, al preguntarle cuál es su estirpe divina. Brilla en lo alto con luz propia, generada a través de generaciones de ser estrella, acumuladas en ella cual Vía Láctea (¿el poder social?).

La hablante lírica se sitúa frente a su referente de modo dialógico y establece cercanía con ella mediante el tuteo. Cree Gabriela haber intercambiado palabras con esa mujer, pero no, nunca sonaron, fue en un sueño de la poetisa ${ }^{44}$. Sueño confirmado

${ }^{43}$ Por la correspondencia de fechas, pose y colorido, pienso que el retrato de María Letelier a que se remite la Mistral es el publicado en El Mercurio del 23 de diciembre de 1914.

${ }^{44}$ El sueño, vínculo con el inconsciente y el imaginario, con el retorno de lo reprimido. 
como real al sentir, al despertar, el perfume de la reina en "almohada y sien": han dormido en el mismo lecho y Gabriela ha recibido el beso de ella en la sien. La identidad femenina entre ellas es así anterior a la irrupción de lo simbólico.

Concluye Gabriela su poema al retrato de la Reina María Letelier de modo dramático:
Reina de la pestaña fina que me ha ocultado tu mirar, ¡ah! cómo esta agria campesina de alma fragosa te va a amar!

Desde tu breve cartulina, Reina de la pestaña fina, ¿no me querrás melificar?

María le "oculta el mirar" a Gabriela, no hay ojo a ojo entre ellas, ese juego de complicidades practicado con desenfreno en ese tiempo. Por primera vez, la voz narrativa se identifica, y lo hace como "agria campesina". Se aclara el reiterado uso de metáforas de la naturaleza, del campo, nunca de la ciudad o de la modernidad en la que María Letelier se inserta, con su traje de cuello de piel blanco, su peinado a la moda, su accesibilidad mediada por una foto retocada en el estilo evanescente de la melancolía, de la seducción de perfil.

La hablante lírica, en un brusco giro final, desnuda su subjetividad y posición social, establece el contraste crudo con la anterior: agria versus licor, campesina arraigada al suelo y a la labor versus esa mujer celestial e incorpórea, hecha de luz, de flor, de líquido ardiente-congelado. Ella, la narradora, tiene alma fragosa, de pasión salvaje, estrepitosa, versus la retenida de la otra que, en cuanto se enciende, se petrifica. Largas generaciones de finura forjaron su cuerpo y estirpe no terrenas, y el amor le dio su cualidad aérea musical.

Esa mujer de la cartulina, enclavada en el acotado papel, es pura representación desplegada entre el imaginario y lo simbólico. Su rezumo alegórico no es la pupila que mira sino la que oculta, que vela el mirar con la pestaña, de modo en extremo sensual. Estos dos seres ni siquiera antagónicos, sino que hechos enteramente de otro material, habitantes de distintas galaxias, ¿pueden conectarse en la realidad, y eventualmente, amarse? No, solo en sueños y en el deseo desesperado de Gabriela, quien la llama a establecer una conexión que únicamente la Reina puede iniciar.

La relación que establece Gabriela con María es muy otra de la del poeta trovador con su musa. Gabriela se sitúa dialógicamente con ella y no en actitud de poder, encubierto como vasallaje. No la quiere como inspiración sino como cuerpo-flujo conectado en el plano de la realidad, a la vez sugerido y negado en su posibilidad de realización. La hablante pide a la reina del retrato la fluidez directa del cuerpo a cuerpo, el elixir de su ser destilado como miel, entregado a su boca amarga de campesina, para así poder situarse en un plano de correspondencia y, desde él, tal vez, amarla. Ella, la voz de la enunciación, está en estado de pura carencia, de deseo vivo, en necesidad de fusión con el símbolo de la plenitud de lo Otro, de lo que ella no es (Reina) y quisiera ser/poseer. Pide que la dulcifique y también que la acalle, porque de ser "melificada", en la plenitud no habría poesía. 


\section{COROLARIO}

¿Quién es y no es la Flor Natural? La Reelaboración del GÉNero Realizada por la MistRAL

En Con su retrato, la Mistral no se atiene a los arquetipos duales y excluyentes de los dos sexos heterosexuales de referencia obligada en esa cultura dominante chilena del Centenario. Desde una fuerte ambigüedad y mediante la enunciación dialógica, atrae hacia sí a la otra, a la deseada, con el poder de la palabra. El gesto de ella de negar su cuerpo físico en la performance pública de "arte, lujo y belleza" de los Juegos Florales, y de presentarse luego con el cuerpo de la palabra poética ante la aclamada Reina de estos, constituyó su propia performance para evidenciar la condena que la sociedad establecida (incluida la de los poetas partícipes de las instituciones oficiales) realiza de su raigambre campesina y de su condición femenina, abiertas como llaga ante la dolorosa conciencia de su inadecuación tanto en lo público (ceremonial) como en lo íntimo (relación amorosa imposible con María Letelier).

Esta misma situación de anómala e incongruente en cuanto a in-corporación de clase y género respecto a las exigencias sociales y culturales de la época, la manifiesta en su nutrida y refinada correspondencia con su amor platónico, el poeta Manuel Magallanes Moure. Su permanente sustraerse al encuentro corpóreo con él, pospuesto por largos y ansiosos años en los cuales nunca acude a las citas, podrían explicar este su desesperado llamado a la Flor Natural de los Juegos Florales, María Letelier, a que la "melifique", llamado hecho desde su propia condición de reina imposible, inactualizable en esa performance.

Así lo expresa Gabriela sin rodeos a Magallanes, justificando su temor a un encuentro personal y, en definitiva, su negativa a encontrarse de cuerpo presente con él:

Tú no serás capaz (interrógate a ti mismo) de querer a una mujer fea. ... Dime la verdad, Manuel. ¿Tan grande es la ceguera que tú mismo te has dado que nunca has pensado en lo que puede resultar de nuestro encuentro? ... ¿Serás capaz, te dejará la bondad ser honrado para no tocarme, para no decirme una palabra más de cariño, después del desengaño? ... Tú, ¿me querrás fea?" (Cartas 59 y 61).

A un escaso mes de estos marcadores Juegos Florales, en enero 26 de 1915, Gabriela atribuye a Manuel Magallanes la cualidad de Flor Natural, de verdadera flor en un sentido religioso-místico de "amor a los seres". Desde su adscripción a la teosofía, para ella la flor no es un atributo asignado por la naturaleza a un sexo (el femenino) sino que todas las personas la poseen en diversas gradaciones; la flor es una conquista, una lucha, y ella aun no la posee ${ }^{45}$. Le escribe:

${ }^{45}$ En ello se reconoce su cercanía con el "Espiritualismo de vanguardia" y con la Teosofía, que comparte con otras escritoras y escritores, en general, aristocráticos (Subercaseaux 68). 
Siempre pensé en que lo que es la flor misma, la coronación de mi religión, el amor a los seres está en Ud. mucho más que en mi. En Ud. es estado cotidiano, en mí florece después de luchas reñidas con mi ángel malo. Siempre lo vi como Ud. se me presenta: con un alma no viril (por virilidad entienden casi todos la rudeza), y sufre siempre que va por sus venas no la sangre espesa que da las pasiones comunes ... sino un zumo azul de azucenas exprimidas (Cartas 27 y 30 ).

De las mismas azucenas de las que estaba hecha María Letelier... Continúa Gabriela: "Cada día veo más claramente las diferencias dolorosas que hay entre Ud. -luna, jazmines, rosas- y yo, una cuchilla repleta de sombra, abierta en una tierra agria. Porque mi dulzura, cuando la tengo, no es natural, es una cosa de fatiga, de exceso de dolor". Luego, reafirma: "Ud. con su pasta de lirios, a qué zonas entraría, qué corrientes de luz eterna atraería a su mar...”. María Letelier y Manuel Magallanes sí son equivalentes, son ambos pasta de luna, de jazmines, de lirios. Son ambos Flores Naturales. Ella, Gabriela, no lo es; de nuevo, menciona su ser campesino "abierto en tierra agria": rara vez es flor, y cuando llega a serlo, lo es trabajosamente.

Quizás también por eso, por su hondo sentido ético y apreciación crítica de sí, no solo en su apariencia sino en su ser profundo, espiritual, no podía ella coronarse en público como la Flor Natural de esos Juegos Florales en la gran performance realizada en el Teatro Santiago en el verano de 1914. Al marginarse de la fiesta de premiación mediante la sustracción de su cuerpo del escenario público y al apersonarse luego con su texto poético frente a la Reina de los Juegos, exponiendo sus carencias y deseos de "agria mujer campesina", creo que la Mistral aprovecha y disloca las reglas de dicho certamen espectacular. Con ese doble gesto, evidencia ambiguamente su condición de incongruente y anómala en tanto cuerpo/género/clase/etnia respecto a lo esperado del ganador de "este magno concurso de arte, lujo y belleza" (Santiván, Confesiones) y deja fluir luego sus deseos en fuga desde lo subalterno en relación con lo dominante. En tanto mujer desterritorializada que busca su lugar desde su propia raigambre y condición, hace efectiva una voz poética que explora con valentía en la herida personal y social, y no cede ni delega a lo masculino dicha capacidad.

Es el caso de Iris, por ejemplo, a quien la Mistral escribe una carta a través de Sucesos el 18 de marzo de 1915, en la que la insta a fundar en Santiago una Sociedad Teosófica de la cual ella probablemente habría querido ser parte (Vargas 33-34). También el de Luisa Lynch, futura presidenta del Club de Señoras, quien en consonancia con el concepto de flor empleado por la Mistral, la espiritualiza en una entrevista ofrecida justamente en 1914, y proyecta al ser humano en cuanto tal en ella como plegaria, alma, elevación, conexión con el conocimiento suprasensible: “-¿Ama Ud. las flores?” Asombrada:-¿Pero no sabe Ud. que en cada flor hay un alma que se exhala en perfume? - ¿Y ama Ud. el silencio? -Lo amo, porque en el silencio hay voces que nos hablan cosas extrañas y profundas...”. 
Realizó así una subversión trascendental, como acto y como palabra, a la excluyente y estereotipada performance de los Juegos Florales acerca de la poesía, el género y la clase/etnia, inscrita en la parafernalia de la Belle Epoque chilena, en tanto actualización local de rituales vigentes en la Europa de la Era del Imperio.

\section{BIBLIOGRAFÍA}

Alegría, Ciro. Gabriela Mistral íntima. Lima: Universo, 1968.

Barros de Orrego, Martina. Recuerdos de mi vida. Santiago: Orbe, 1942.

Bourdieu, Pierre. Las reglas del arte. Génesis y estructura del campo literario. Barcelona: Anagrama, 1995.

Butler. Judith. Bodies that matter. New York: Routledge, 1993.

Burke, Peter. Popular culture in early modern Europe. Cambridge: University Press, $2^{\circ}$ ed., 1994.

Catalán, Gonzalo. "Antecedentes sobre la transformación del campo literario en Chile entre 1890-1920”. Cinco estudios sobre cultura y sociedad. J. J. Brunner y Gonzalo Catalán. Santiago: FLACSO, 1995.

Chilean Government. Chile 1915. Santiago: Zig-Zag, 1915.

Collier, Simon y William F. Sater. Historia de Chile 1808-1994. Cambridge: University Press, 1998.

Darwin, Charles. The origin of species. Garden City: Doubleday, 1859.

Debord, Guy. The society of the spectacle. New York: Zone Books, 1994.

De Lys, Xavier. "La noche de los juegos florales". El libro de los Juegos Florales. Santiago: Lom, 2000. 23-26.

Dias, Nélia. "O corpo e a visibilidade da diferença". Corpo presente. Treze reflexoes antropológicas sobre o corpo. Org. Vale de Almeida. Oeiras: Celta, 1996. 23-44.

Echeverría Bello, Inés. Memoria de Iris 1899-1925. Santiago: Aguilar, 2005.

El Mercurio. "Los Juegos Florales". El Mercurio (23-12-1914).

Foucault, Michel. Los anormales. Buenos Aires: F.C.E, 2001.

Gazmuri, Cristián. "El triunfo de la clase media". Revista Universitaria PUC. 97 (2007): 611.

Habermas, Jurgen. Historia y crítica de la opinión pública. Transformación estructural de la vid pública. Barcelona: Gustavo Gili, 1999.

Hobsbawm, Eric. La era del imperio, 1875-1914. Buenos Aires: Grijalbo Mondadori, 1998. Hunt, Lynn. "Freedom of dress in revolutionary France". Feminism and the body. Ed. Londa Schiebinger. Oxford: University Press, 2000. 183-202.

Hurtado, M. de la Luz. "La tapada, la performance chilena del mirar sin dejarse mirar". Apuntes 125 (2004): 43-59.

Teatro chileno y modernidad: identidad y crisis social. Irvine: Gestos, 1997.

Krebs, Ricardo. "Apuntes sobre la mentalidad de la aristocracia chilena en los comienzos del siglo XX". Historia de las mentalidades, Valparaíso: Edeval, 1986. 27-55.

Lynch de Gormaz, Luisa. "Entrevista con una gran dama". Con Claudio de Alas. Zig-Zag 493 (1914). 
Mistral, Gabriela. "Con su retrato". 1915. El libro de los juegos florales. Santiago: LOM, 2000. 71-73.

Gabriela Mistral. Cartas de amor y desamor. Santiago: Andrés Bello, 1999.

Mont-Calm (Carlos Varas M.). "El Museo Boncompagni”. Zig-Zag. 169 (1908).

Muguet. "En el gran mundo". Familia 21 (1911): 11.

Ortiz, Renato. "Modernidad y espacio". Benjamin en Paris. Bogotá: Norma, 2000.

Pernoud, Régine. La mujer en el tiempo de las catedrales. Santiago: Andrés Bello, 1999.

Perrot, Michelle. Mujeres en la ciudad. Santiago: Andrés Bello, 1997.

Rama, Ángel. La ciudad letrada. Hanover-New Hampshire: del Norte, 1984.

Rojo, Grínor. “Clásicos latinoamericanos. Para una relectura del canon”. Inédito. 2001.

Roxane (Elvira Santa Cruz de Ossa). "Vida social". Zig-Zag 501 (1914).

Santiván, Fernando. "La moda femenina”. Zig-Zag 374 (1912).

“Confesiones de Santiván: recuerdos literarios". Obras completas. Santiago: ZigZag, 1965.

Sennett, Richard. Carne y piedra. El cuerpo y la ciudad en la civilización occidental. Madrid: Alianza, 1997.

Silverman, Kaja. The threshold of the visible world. New York \& London: Routledge, 1996.

Simona. "Figuras femeninas de pasados tiempos. Clemencia Isaura y los juegos florales". Familia 177 (1924): 3.

Subercaseaux, Bernardo. Genealogía de la vanguardia en Chile. Santiago: U. de Chile, 1998.

Vargas Saavedra, Luis, M. E. Martínez, R. Valdés. En batalla de sencillez. Epistolario de Gabriela Mistral a Pedro Prado. Santiago: Dolmen, 1993.

Vicuña Mackenna, Benjamín. "El baile improvisado de la Quinta Meiggs". 1866. Familia. 176 (1924): 1.

La transformación de Santiago. Santiago: Librería de El Mercurio de Orestes L. Tornero, 1872.

Vicuña, Manuel. La Belle Epoque chilena. Santiago: Sudamericana, 2001.

El París americano. La oligarquía chilena como actor urbano en el siglo XIX. Santiago: U. Finis Terrae, 1996.

Wagner, Peter. A sociology of modernity. Liberty and discipline. USA-Canada: Routledge, 1994.

Wanderer. "Las grandes elegancias y su espíritu". Zig-Zag 272 (1910): 5-7.

Zig-Zag. "Los Juegos Florales de 1914”. Zig-Zag (26-12-1914).

PALABRAS ClAVE: género, clase, parafernalia modernista, relación poeta/musa, Gabriela Mistral. KEY WORDS: gender, class, modernist paraphernalia, poet/muse relationship, Gabriela Mistral. 